\title{
In vitro study on effect of bardoxolone methyl on cisplatin-induced cellular senescence in human proximal tubular cells
}

\author{
Yoshifumi Kurosaki ${ }^{1}$ (D) Akemi Imoto ${ }^{1} \cdot$ Fumitaka Kawakami $^{1} \cdot$ Motoshi Ouchi $^{2} \cdot$ Asuka Morita $^{2} \cdot$ Masanori Yokoba $^{3}$. \\ Tsuneo Takenaka ${ }^{4} \cdot$ Takafumi Ichikawa $^{1} \cdot$ Masato Katagiri $^{3} \cdot$ Rikke Nielsen $^{5} \cdot$ Naohito Ishii $^{1}$
}

Received: 9 June 2021 / Accepted: 4 November 2021 / Published online: 1 January 2022

(c) The Author(s) 2021

\begin{abstract}
Bardoxolone methyl [methyl-2-cyano-3, 12-dioxooleana-1, 9(11)dien-28-oate (CDDO-Me)], an activator of the nuclear factor erythroid-derived 2-related factor2 pathway, is a potential therapeutic candidate for the treatment of kidney diseases. However, its effect against cellular senescence remains unclear. This study aimed to investigate whether CDDO-Me protects cells against cisplatin-induced cellular senescence using an in vitro model. The human renal proximal tubular epithelial cell line HK-2 was treated with cisplatin for $6 \mathrm{~h}$, followed by treatment with or without CDDO-Me $(0.1$ or $0.2 \mu \mathrm{mol} / \mathrm{L})$. Senescence markers were analyzed using western blotting and real-time PCR. Apoptosis was evaluated through TUNEL staining. Cisplatin induced changes in the levels of markers specific for proliferation, cell cycle, and senescence in a time- and dosedependent manner. Furthermore, IL-6 and IL-8 levels in the culture medium increased markedly. These data suggested that cellular senescence-like alterations occurred in HK-2 cells exposed to cisplatin. CDDO-Me treatment reversed the cisplatinmediated alterations in the levels of cellular senescence markers. The antioxidant enzymes, HO1, NQO1, GPXI, and CAT were upregulated by CDDO-Me treatment. Furthermore, CDDO-Me treatment induced apoptosis in cisplatin-exposed HK-2 cells. Pretreatment with Ac-DEVD-CHO, the caspase inhibitor, suppressed the reversal effect of CDDO-Me against cisplatininduced cellular senescence-like alterations. This study showed that CDDO-Me attenuated cisplatin-induced premature senescence of HK-2 cells. This beneficial effect may be related to Nrf2 activation. Our findings also showed that CDDO-Me induced apoptosis in cisplatin-treated HK-2 cells, potentially protecting the kidneys from cellular senescence. CDDO-Me appears to be a candidate treatment for acute kidney injury.
\end{abstract}

Keywords CDDO-Me $\cdot$ Cellular senescence $\cdot$ Acute Kidney injury $\cdot \mathrm{Nrf2} \cdot$ Apoptosis

\section{Introduction}

Yoshifumi Kurosaki

kuro96@kitasato-u.ac.jp

1 Department of Molecular Medical Biology, Kitasato University Graduate School of Medical Sciences, Kitasato 1-15-1, Minami-ku, Sagamihara-shi, Kanagawa 252-0373, Japan

2 Department of Pharmacology and Toxicology, Dokkyo Medical University School of Medicine, Tochigi, Japan

3 Department of Clinical Medicine, Kitasato University Graduate School of Medical Sciences, Kanagawa, Japan

4 Department of Nephrology, International University of Health and Welfare Graduate School of Medicine, Tokyo, Japan

5 Department of Biomedicine, Aarhus University, Århus, Denmark
Acute kidney injury (AKI) is a complex syndrome characterized by renal dysfunction and is associated with high morbidity and mortality worldwide. Patients with post-AKI are at an increased risk for chronic kidney disease, CKD [1-3]. Proximal tubule injury caused by AKI triggers several features of CKD by inducing inflammation and interstitial fibrosis [4]. Therefore, it is important to protect the proximal tubules for preventing the progression of AKI to CKD; however, the definitive evidence for this effect is lacking.

There is an association between cellular senescence in proximal tubular epithelial cells (PTCs) and CKD in the animal models of hypertension [5] or diabetes [6]. Senescence is a tumor suppressor mechanism by which cells adapt to DNA damage, oxidative stress, and telomere shortening. Senescence induces cell cycle arrest in cells exposed to various stresses 
[7, 8]. Senescent cells secrete pro-inflammatory molecules in order to recruit immune cells. This behavior is termed as senescence-associated secretory phenotype, SASP [9]. These pro-inflammatory molecules, including cytokines and chemokines, can lead to the clearance of senescent cells in the damaged tissue $[10,11]$. In contrast, the chronic secretion of these SASP factors promotes inflammation and epithelialto-mesenchymal transition, thereby reducing the functional reserve of tissues. Thus, senescence is protective in the acute phase; however, chronic senescence can be harmful to tissue homeostasis. Senescent cells undergo an anti-apoptotic state [12-14], leading to the constitutive secretion of SASP factors. Chronic secretion of SASP factors can spread senescence to nearby cells [15]; therefore, the removal of senescent cells by activating apoptosis seems to be a critical mechanism for protecting the proximal tubule and preventing CKD progression. In fact, much effort has been made to eliminate senescent cells using novel drugs called senolytics. These drugs remove senescent cells by inducing apoptosis [16] or by blocking their resistance to apoptosis [17, 18]. Therefore, protecting PTCs from cellular senescence could prevent CKD development; however, effective treatments that target senescence are lacking.

Methyl-2-cyano-3, 12-dioxooleana-1, 9(11)dien-28-oate (CDDO-Me), also known as bardoxolone methyl, is a semisynthetic triterpenoid and the most potent activator of the nuclear factor erythroid-derived 2-related factor2 (Nrf2) pathway [19-21]. Besides activating Nrf2, CDDO-Me upregulates the antioxidant response and suppresses pro-inflammatory signaling reducing oxidative stress and inflammation, and promoting mitochondrial function [22, 23]. CDDO-Me and its analogs have beneficial effects on CKD associated with type 2 diabetes [24, 25], obesity [26], and angiotensin-induced kidney injury [27]. Furthermore, CDDO-Me induces apoptosis [28]; therefore, CDDO-Me could be beneficial for eliminating cellular senescence. CDDO-Me is an attractive therapeutic candidate for managing cellular senescence in kidney diseases, but the precise effects remain unknown.

Cisplatin is one of the most widely used anti-cancer drugs; however, its use is limited because of its nephrotoxicity, which causes AKI [29]. Cisplatin treatment is widely used as a model for AKI; it induces cellular senescence, both in vitro [30,31] and in vivo $[32,33]$. The aim of this study was, therefore, to investigate whether CDDO-Me protects PTCs against cisplatin-induced cellular senescence to explain the beneficial effect of CDDO-Me.

\section{Materials and methods}

\section{Cell culture}

The human renal proximal tubular epithelial cell line HK-2 was cultured in Dulbecco's Modified Eagle's Medium: Nutrient Mixture F-12 (DMEM/F12, Fujifilm Wako Chemical Co., Osaka, Japan) supplemented with $10 \%$ fetal bovine serum (FBS, Biosera, Inc., Nuaille, France) and $1 \%$ penicillin-streptomycin, as previously described [34]. Cells were treated with $0-50 \mu \mathrm{mol} / \mathrm{L}$ cisplatin in low-glucose DMEM containing $0.1 \mathrm{mg} / \mathrm{mL}$ human serum albumin for $6 \mathrm{~h}$. The medium was then replaced with fresh medium with or without $0.1-0.2 \mu \mathrm{mol} / \mathrm{L}$ CDDOMe (Sigma-Aldrich Co., St. Louis, MO, USA). The cells were treated with 5 or $50 \mu \mathrm{mol} / \mathrm{L}$ of the caspase inhibitor, Ac-DEVD-CHO (Selleckchem, Houston, TX, USA), for $60 \mathrm{~min}$ before adding CDDO-Me to the medium. Cells were cultured for $24-72 \mathrm{~h}$, and proteins or mRNA were extracted at the indicated points.

\section{Western blot (WB) analysis}

The cultured cells were solubilized in lysis buffer ( $150 \mathrm{mmol} / \mathrm{L} \mathrm{NaCl}, 50 \mathrm{mmol} / \mathrm{L}$ Tris$-\mathrm{HCl}, 5 \mathrm{mmol} / \mathrm{L}$ EDTA-2Na, $1 \%$ Triton X-100, and 1 tablet $/ 10 \mathrm{~mL}$ complete mini EDTA-free) and centrifuged at $15,000 \times g$ at $4{ }^{\circ} \mathrm{C}$ for $30 \mathrm{~min}$. Samples were separated by SDS-PAGE and then transferred to PVDF membranes. The membranes were first blocked in a buffer containing $25 \mathrm{mmol} / \mathrm{L}$ Tris- $\mathrm{HCl}$ (pH 7.4), $150 \mathrm{mmol} / \mathrm{L} \mathrm{NaCl}, 0.1 \%$ Tween 20 , and $4 \%$ skim milk for $1 \mathrm{~h}$ and then incubated with primary antibodies at $4{ }^{\circ} \mathrm{C}$ overnight. This was followed by incubation with horseradish peroxidase-conjugated secondary antibodies for $1 \mathrm{~h}$. Primary antibodies against human p2 $1^{\text {Waf1/Cip1 }}, \mathrm{p} 16^{\text {INK4a }}$, phosphorylated H2AX (Ser139, $\gamma-\mathrm{H} 2 \mathrm{AX})$, retinoblastoma $(\mathrm{Rb})$, phosphorylated $\mathrm{Rb}$ (Ser780, pRb), cyclin D, and caspase-3 were all purchased from Cell Signaling Technology, Inc. (Beverly, MA, USA). Antibodies against human cyclin A (Novocastra Laboratories Ltd., Newcastle, UK), p16 ${ }^{\mathrm{INK} 4 \mathrm{a}}$ (BD Biosciences, Inc., Farmingdale, NY, USA), Ki-67 (Dako from Agilent, Santa Clara, CA, USA), p62/SQSTM1, and $\beta$-actin (Santa Cruz Biotechnology, Santa Cruz, CA, USA) were also used. The immunoreactive proteins were then detected by enhanced chemiluminescence (GE Healthcare, Fairfield, CT, USA). Immunoblots were quantified using the CS Analyzer 3.0 software (ATTO, Tokyo); $\beta$-actin expression was used as the internal control. 
A
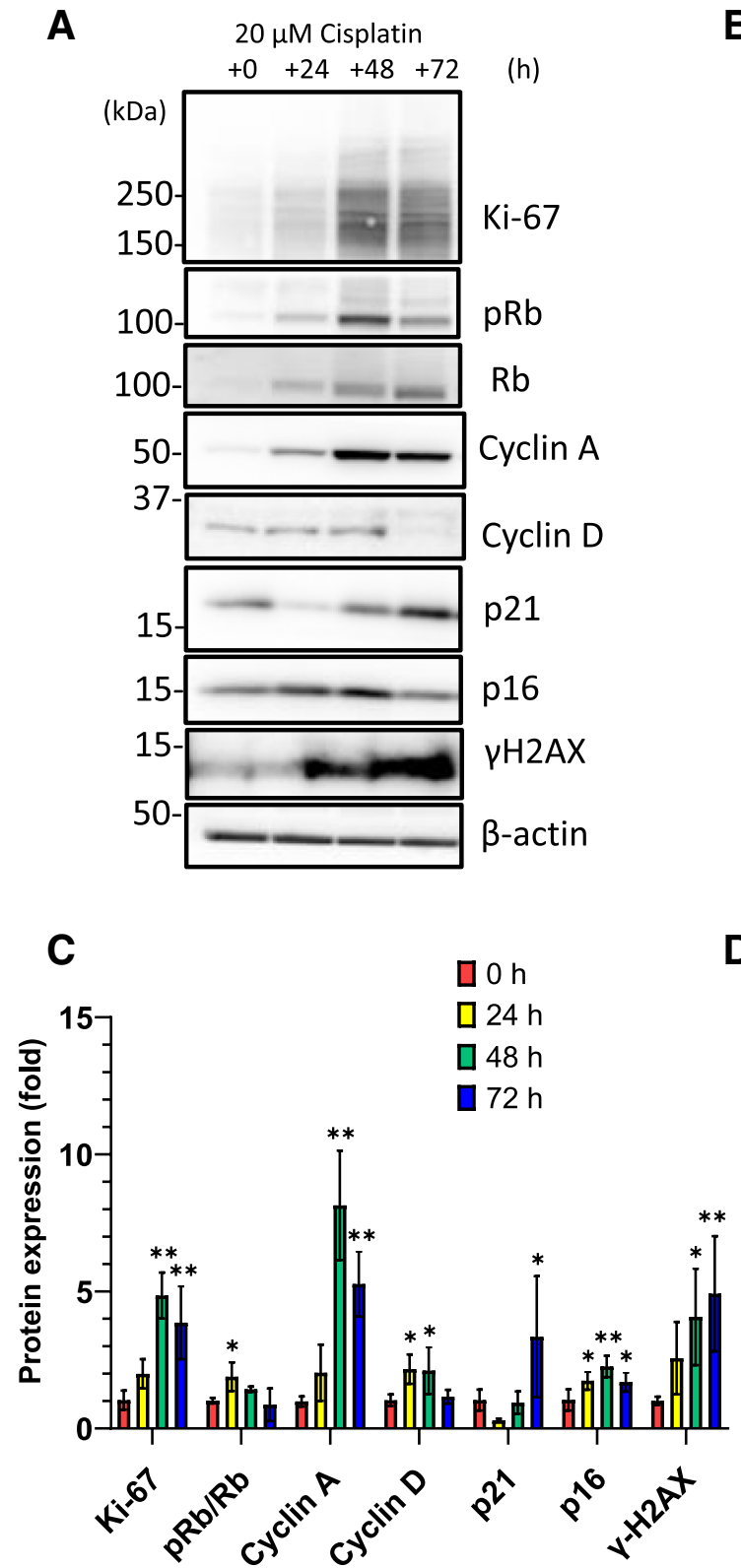

Fig. 1 Cisplatin induces cellular senescence-like alterations in HK-2 cells. HK-2 cells were treated with $0-50 \mu \mathrm{mol} / \mathrm{L}$ cisplatin, and western blot analysis revealed changes in the expression levels of prolifer-

\section{Real-time reverse transcription-PCR (RT-qPCR)}

Total RNA and cDNA from HK-2 cells were prepared using the ISOGEN-II (Nippon Gene, Tokyo) and Prime Script RT-PCR kits (Takara Bio, Shiga), according to the manufacturer's instructions. The primers used for qPCR are shown in Supplementary Table 1. qPCR was performed on a 7500 Real-Time PCR System (Applied Biosystems) in a 96-well reaction plate using Power SYBR Green. The mRNA expression of the target genes was normalized to that of $G A P D H$, using the delta-delta $C_{\mathrm{t}}$ method.
B

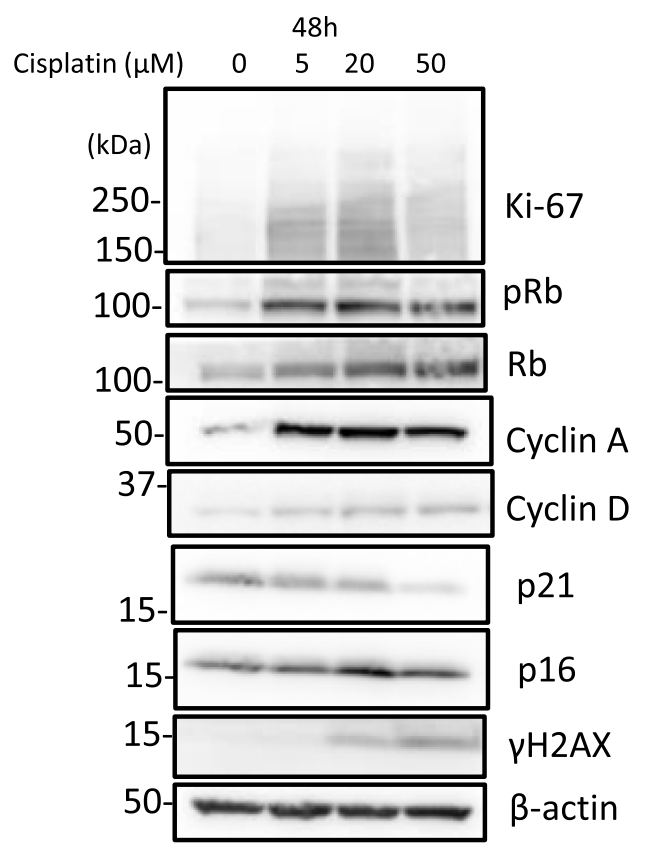

D

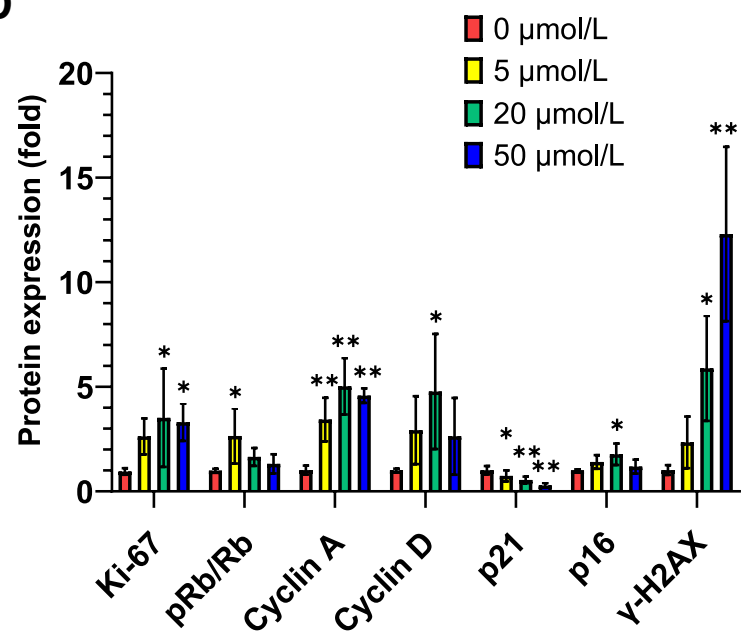

ation, cell cycle, and senescence markers in a time- $(\mathbf{A})$ and dose- $(\mathbf{B})$ dependent manner. Densitometric analysis is shown in C-D. $n=4-6$, $* P<0.05, * * P<0.01$

\section{Cell cycle analysis using flow cytometry}

HK-2 cells were harvested, washed, and resuspended in phosphate buffered saline. Cells were then fixed with $70 \%$ ethanol and stored at $4{ }^{\circ} \mathrm{C}$ overnight. Subsequently, cells were incubated with $100 \mu \mathrm{g} / \mathrm{mL}$ RNase for $30 \mathrm{~min}$ at $37{ }^{\circ} \mathrm{C}$ and stained with $5 \mu \mathrm{g} / \mathrm{mL}$ propidium iodide (PI) for $10 \mathrm{~min}$. Flow cytometry analyses were performed using a BD FACSCalibur (BD Biosciences). Cell cycle phase distributions were determined using Modfit LT software version 3.0 (Verity Software House, Topsham, ME, USA). 
A
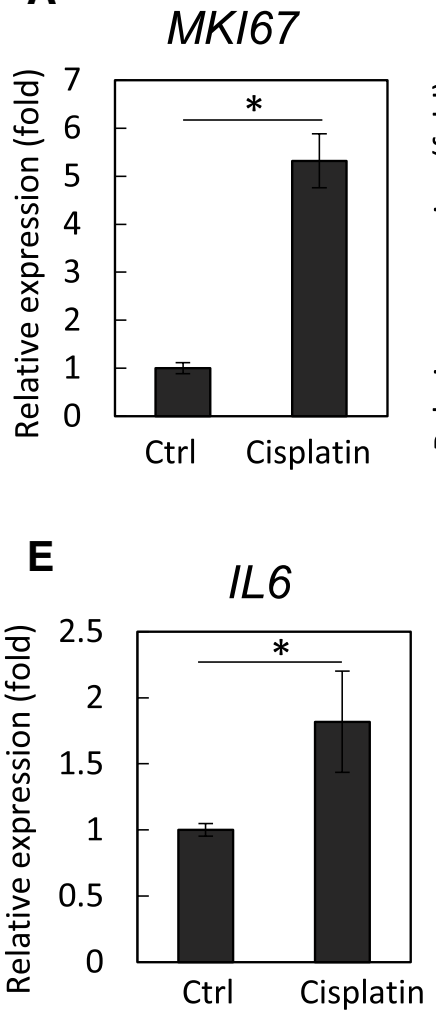

B

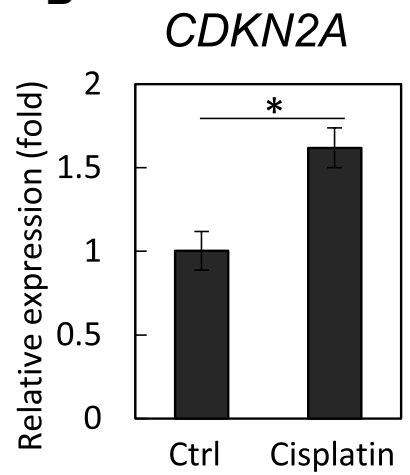

$\mathbf{F}$

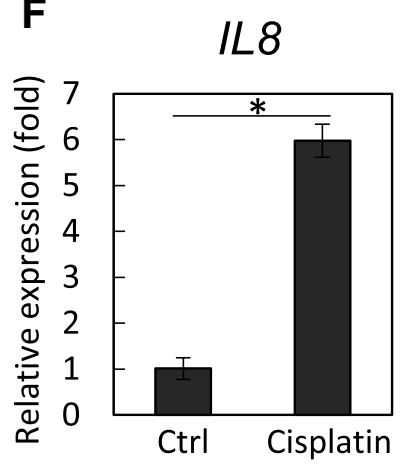

C

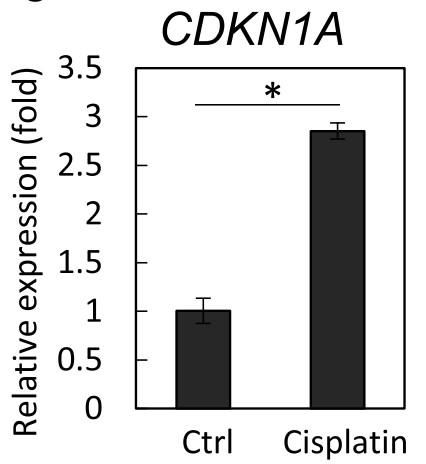

G

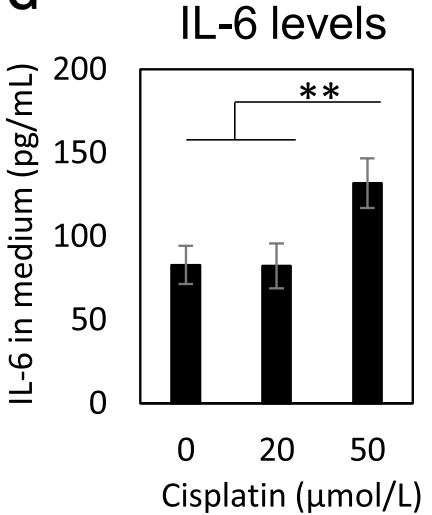

D

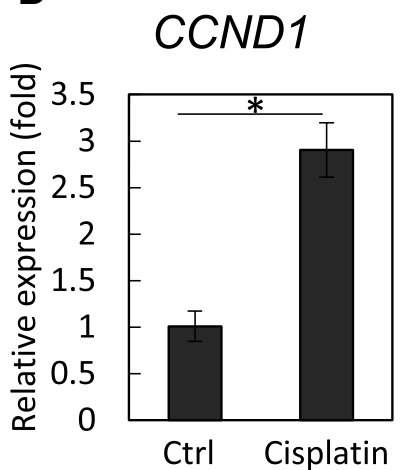

H

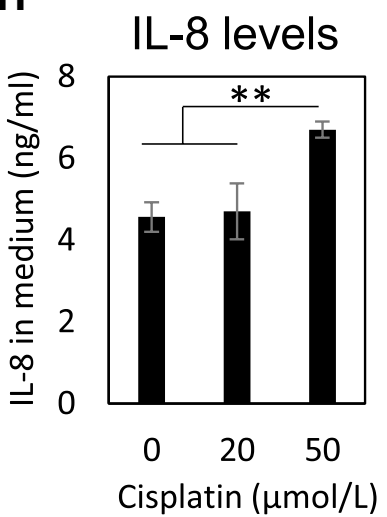

Fig. 2 Cisplatin treatment induces the increase in senescence-related gene transcriptions and cytokine secretion. The mRNA expression of senescence-related genes, MKI67 (A), CDKN2A (B), CDKN1A (C), $C C N D 1(\mathbf{D}), I L-6(\mathbf{E})$, and $I L-8(\mathbf{F})$, after cisplatin $(20 \mu \mathrm{mol} / \mathrm{L})$ treat-

\section{Determination of cytokine levels by ELISA}

Following exposure to cisplatin, supernatants were collected from the culture medium. Cytokine levels were determined using ELISA kits for IL-6 and IL-8 (R\&D Systems, Minneapolis, MN, USA) as per the manufacturer's instructions.

\section{TdT-mediated dUTP-biotin nick end labeling (TUNEL) staining}

TUNEL staining was performed using a commercial kit (Takara Bio), following each treatment described above. The percentage of apoptotic cells was determined by counting the TUNEL-positive cells and the total number of cells (nucleus) in four to six photomicrographs $(\times 200$ magnification, approximately 1500 cells) by a blinded observer.

ment was determined by qPCR. Cytokine levels, IL-6 (G) and IL-8 $(\mathbf{H})$, in cultured medium of cisplatin $(20$ or $50 \mu \mathrm{mol} / \mathrm{L})$-exposed cells were quantified by ELISA. $n=3, * P<0.05, * * P<0.01$

This experiment was performed thrice, on different days. The apoptosis rate was expressed as the means \pm standard deviation (SD) from three independent experiments.

\section{Statistical analysis}

All data are reported as the mean \pm SD. The RT-qPCR and WB analysis data are presented as the fold change relative to the controls (untreated cells). The RT-qPCR data were evaluated using Students $t$-test to assess differences between the control and cisplatin-treated cells. Other data were analyzed using analysis of variance (ANOVA) with post hoc comparisons using the Student-Newman-Keuls method. $P$ values $<0.05$ were considered statistically significant. 
A

$\begin{array}{ccccc}20 \mu \mathrm{M} \text { Cisplatin } & - & + & + & + \\ \text { CDDO-Me }(\mu \mathrm{M}) & - & - & 0.1 & 0.2\end{array}$

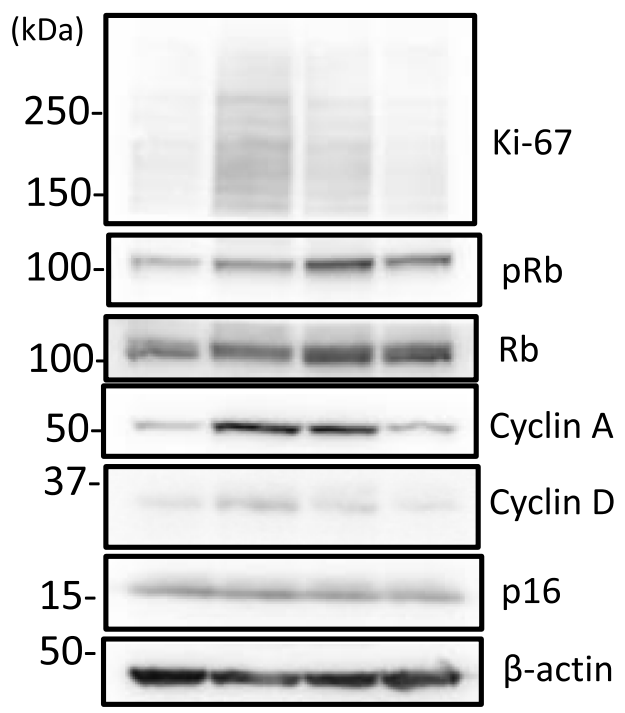

B

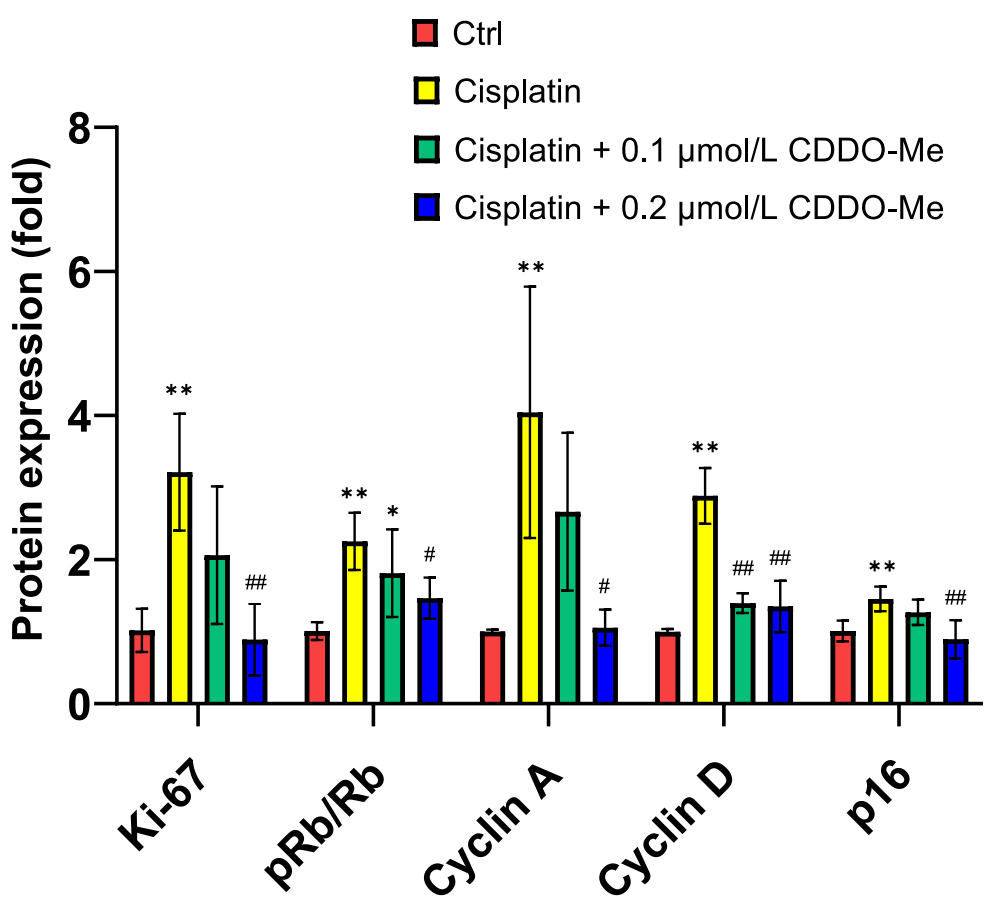

Fig. 3 CDDO-Me treatment reversed the cisplatin-induced cellular senescence phenotype in HK-2 cells. HK-2 cells were exposed to $20 \mu \mathrm{mol} / \mathrm{L}$ cisplatin for $6 \mathrm{~h}$, followed by treatment with or without CDDO-Me $(0.1$ or $0.2 \mu \mathrm{mol} / \mathrm{L})$. Proteins were collected $48 \mathrm{~h}$ after

\section{Results}

\section{Cisplatin treatment induces cellular senescence-like alterations in HK-2 cells}

First, we examined whether cisplatin exposure induces cellular senescence in HK-2 cells. Cisplatin treatment induced alterations in the expression of proliferation, cell cycle, and senescence markers in a time- and dose-dependent manner (Fig. 1). The expression of Ki-67, a proliferation marker, significantly increased after exposure to $20 \mu \mathrm{mol} / \mathrm{L}$ cisplatin; it decreased after exposure to $50 \mu \mathrm{mol} / \mathrm{L}$ cisplatin compared to that after exposure to $20 \mu \mathrm{mol} / \mathrm{L}$ cisplatin. The expression of the cell cycle markers $\mathrm{pRb}, \mathrm{Rb}$, cyclin $\mathrm{D}$, and cyclin A increased in cisplatin-exposed HK-2 cells. Cisplatin treatment increased the levels of $\mathrm{p} 16^{\mathrm{INK} 4 \mathrm{a}}$ in a time-dependent manner. The expression level of $\mathrm{p} 21^{\text {Waf1/Cip } 1}$ was decreased at $48 \mathrm{~h}$; however, it was increased at $72 \mathrm{~h}$. Cisplatin treatment increased the level of $\gamma$-H2AX, a DNA damage marker. The mRNA expression of MKI67 (encoding Ki-67), CDKN1A (encoding p21 ${ }^{\text {Waf1/Cip1 }}$ ), $C D K N 2 A$ (encoding $\mathrm{p} 16^{\mathrm{INK} 4 \mathrm{a}}$ ), and $C C N D 1$ (encoding cyclin D1) increased $48 \mathrm{~h}$ after exposure to $20 \mu \mathrm{mol} / \mathrm{L}$ cisplatin (Fig. 2A-D). Furthermore, the mRNA levels of $I L-6$ and $I L-8$ treatment and analyzed by western blotting (A), and protein bands were quantified by densitometry (B). $n=4-6, * P<0.05$, $* * P<0.01$ vs. control (Ctrl); ${ }^{+} P<0.05,{ }^{++} P<0.01$ vs. cisplatin

increased markedly (Fig. 2E, F). An increase in the cytokine levels was observed in the culture medium of cells exposed to $50 \mu \mathrm{mol} / \mathrm{L}$ cisplatin (Fig. $2 \mathrm{G}, \mathrm{H}$ ). These data suggest that cisplatin treatment induced proliferation, DNA damage, and subsequent cellular senescence-like alterations in HK-2 cells.

\section{CDDO-Me reverses cisplatin-induced cellular senescence-like alterations in HK-2 cells}

CDDO-Me treatment normalized the cisplatin-induced alterations in the expression of the cellular senescence markers Ki-67, cyclin A, cyclin D, pRb/Rb, and p16 $6^{\mathrm{INK} 4 \mathrm{a}}$ in HK-2 cells (Fig. 3). Cell cycle analysis using cytometry revealed that CDDO-Me treatment ameliorated cisplatininduced cell cycle abnormalities (Fig. 4). Cisplatin markedly decreased the percentage of cells in the G1 phase and increased that in the $\mathrm{S}$ phase. The cells in the G2 phase also tended to increase after cisplatin treatment. However, CDDO-Me treatment increased the number of G1-phase cells and decreased that of S- and G2-phase cells. 
A

Ctrl

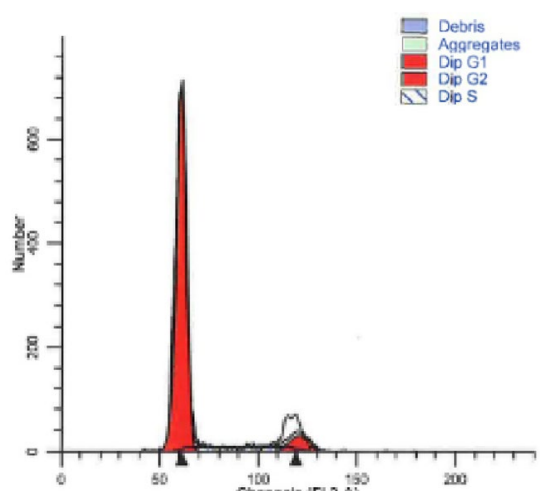

D

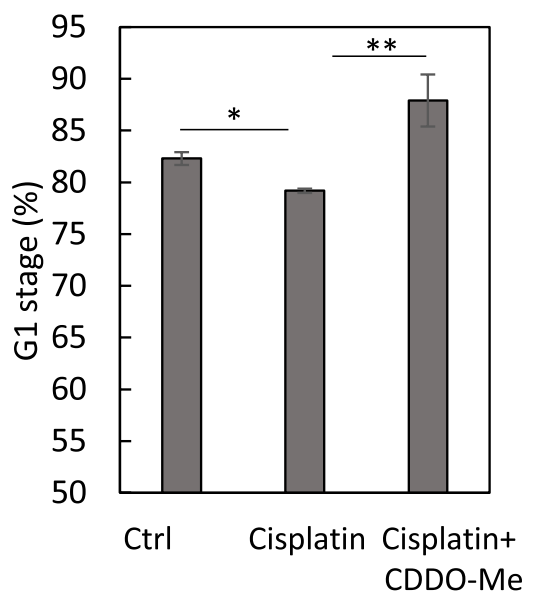

B

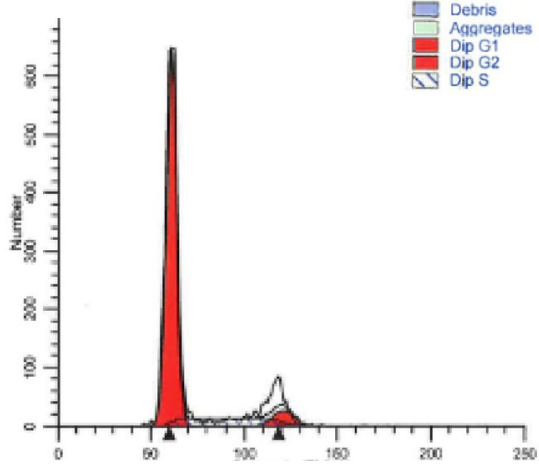

E

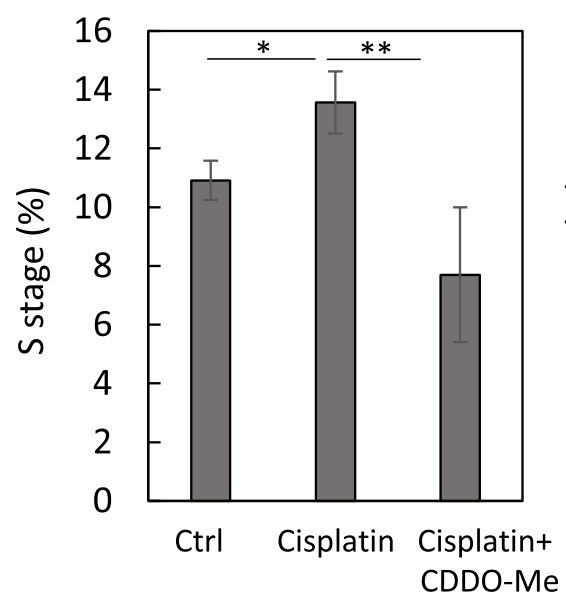

C Cisplatin + CDDO-Me

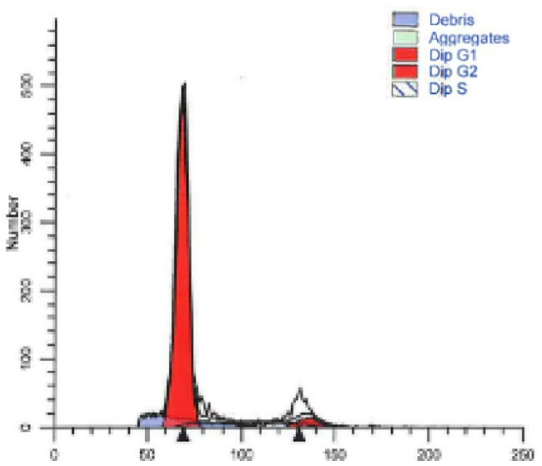

$\mathbf{F}$

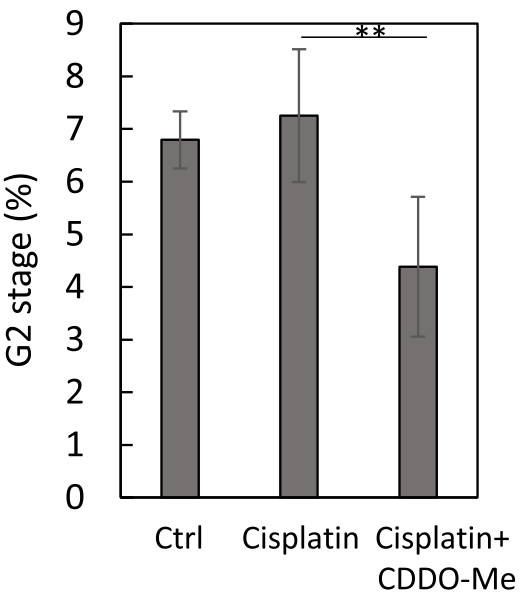

Fig. 4 CDDO-Me protects cells against cisplatin-induced abnormalities in cell cycle. Cisplatin $(20 \mu \mathrm{mol} / \mathrm{L})$-exposed cells were treated with $0.2 \mu \mathrm{mol} / \mathrm{L}$ CDDO-Me for $48 \mathrm{~h}$. Cells were harvested and

\section{CDDO-Me upregulates the expression of antioxidant enzymes}

To evaluate the mechanisms by which CDDO-Me protected the cisplatin-exposed HK-2 cells against cellular senescence-like alterations, we evaluated whether the expression of antioxidant enzyme gene were upregulated under the present conditions (Fig. 5). The mRNA of antioxidant enzymes, heme oxygenase-1 (HOl), NAD(P)H:quinone oxidoreductase (NQO1), glutathione peroxidase 1 (GPXI), and catalase $(C A T)$, were upregulated by CDDO-Me treatment. However, CDDO-Me treatment did not significantly increase the mRNA expression of superoxide dismutase 1 (SOD1). stained with propidium iodide, and then analyzed by flow cytometry (A-C). The statistics of each cell cycle phase (D-F). $n=3,{ }^{*} P<0.05$, $* * P<0.01$

\section{CDDO-Me induces apoptosis in cisplatin-treated HK-2 cells}

The effect of CDDO-Me on apoptosis was evaluated because CDDO-Me treatment significantly decreased the cell number in cisplatin-exposed HK-2 cells (Fig. 6A). CDDO-Me induced apoptosis in cisplatin-exposed HK-2 cells; however, only cisplatin treatment also induced apoptosis, as observed using TUNEL staining (Fig. 6B, C). WB analysis confirmed that CDDO-Me treatment induced apoptosis, decreased the level of pro-caspase-3, and increased the level of cleaved caspase-3 and p62/SQSTM1 in HK-2 cells (Fig. 7A, B). $\mathrm{CDDO}-\mathrm{Me}$ accelerated the phosphorylation of $\mathrm{H} 2 \mathrm{AX}$ in cisplatin-treated HK-2 cells. To elucidate whether CDDO-Me 
A

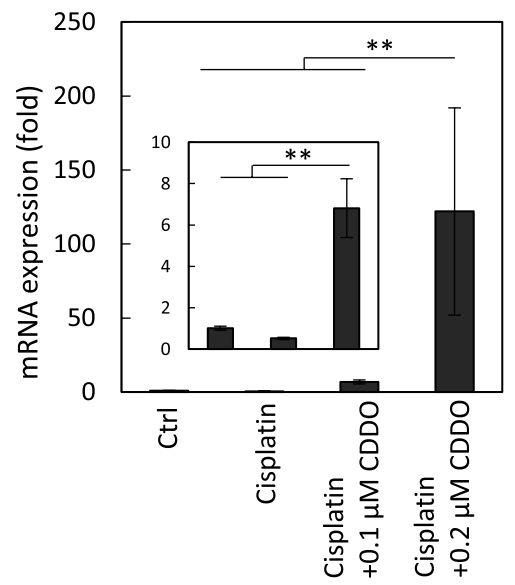

B

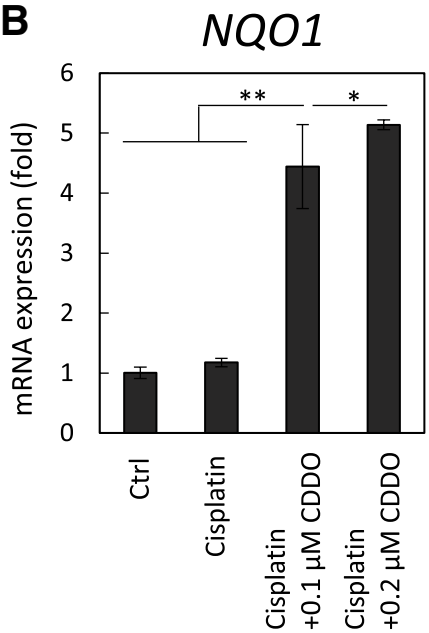

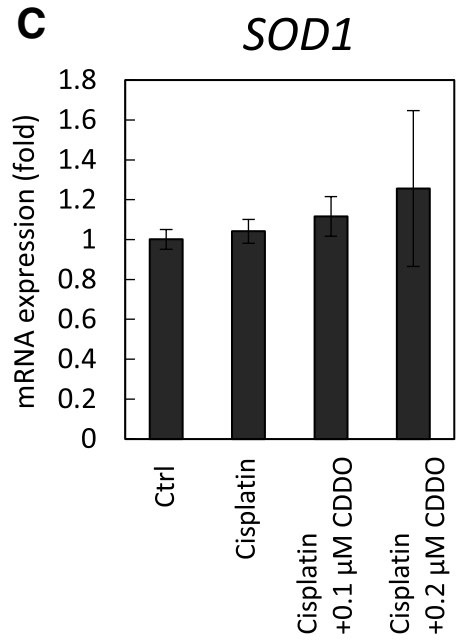

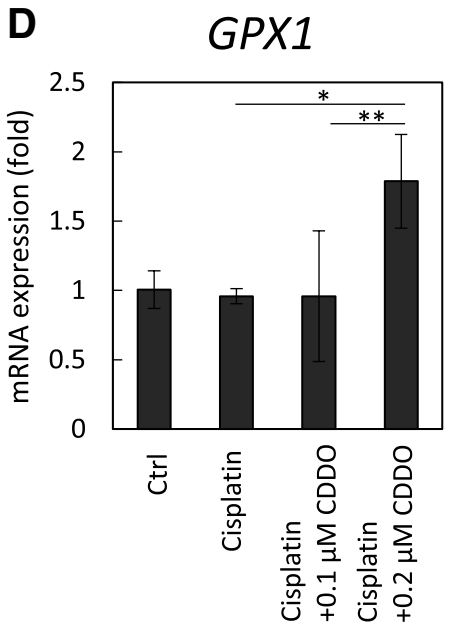

E

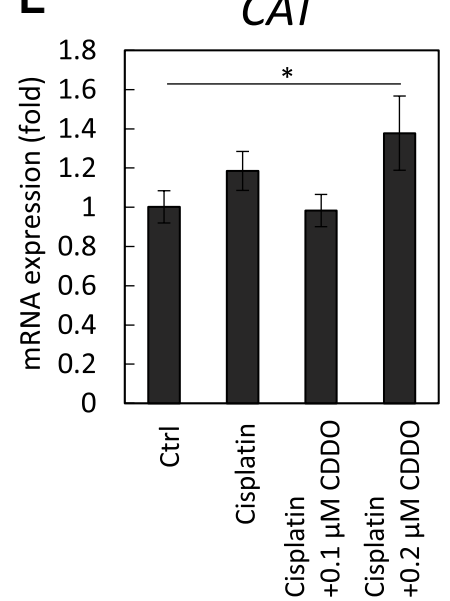

Fig. 5 CDDO-Me induces ARE-related gene transcription by activating the Keap1-Nrf2 pathway. HK-2 cells were exposed to $20 \mu \mathrm{mol} / \mathrm{L}$ cisplatin for $6 \mathrm{~h}$, followed by treatment with or without CDDO-Me $(0.1$ or $0.2 \mu \mathrm{mol} / \mathrm{L})$. The mRNA expression levels of Nrf2-related

reverses cisplatin-induced cellular senescence-like alterations via apoptosis, cisplatin-exposed cells were treated with Ac-DEVD-CHO, a caspase inhibitor, before the CDDO-Me treatment. Ac-DEVD-CHO treatment inhibited the decrease in Ki-67, cyclin A, cyclin D, and p16 ${ }^{\mathrm{INK} 4 \mathrm{a}}$ expression levels induced by CDDO-Me (Fig. 7C, D).

\section{Discussion}

CDDO-Me therapy improves renal function in CKD patients, in clinical trials [24, 25, 35]. However, the renal protective mechanism of CDDO-Me on the AKI-CKD genes were analyzed by qPCR $48 \mathrm{~h}$ after treatment: heme oxygenase-1 (A), NAD(P)H:quinone oxidoreductase $(\mathbf{B})$, superoxide dismutase $1(\mathbf{C})$, glutathione peroxidase $1(\mathbf{D})$, and catalase $(\mathbf{E}) . n=3$, $* P<0.05, * * P<0.01$

transition remains unknown. Protecting the proximal tubules from AKI, which causes cellular senescence, is important for preventing CKD development. This study elucidated the protective effect of CDDO-Me on cisplatin-induced cellular senescence in cultured human PTCs, HK-2, which is one of the most used cells for the study of senescent PTCs [36-38]. In this study, WB analysis revealed an increased expression of Ki-67 in HK-2 cells following cisplatin treatment; chronic increase in proliferation induces cellular senescence in PTCs [39]. Accelerated proliferation may be one mechanism by which cellular senescence is induced in cisplatin-treated cells. In addition to a pool of proliferating cells, elevated cell cycle arrest markers were observed, indicating the presence 

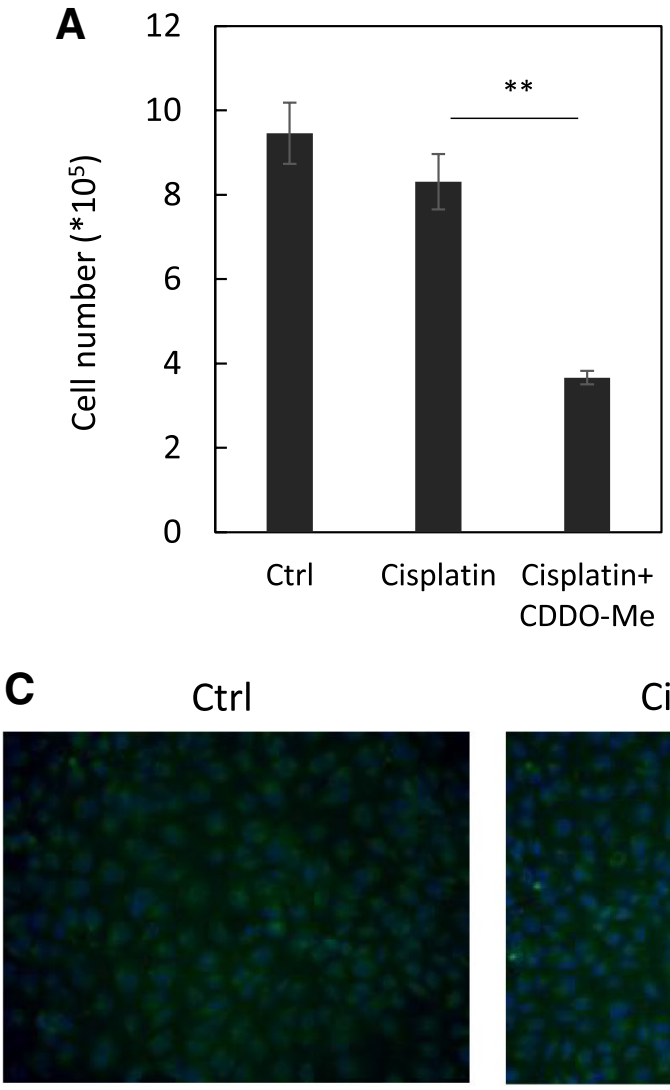
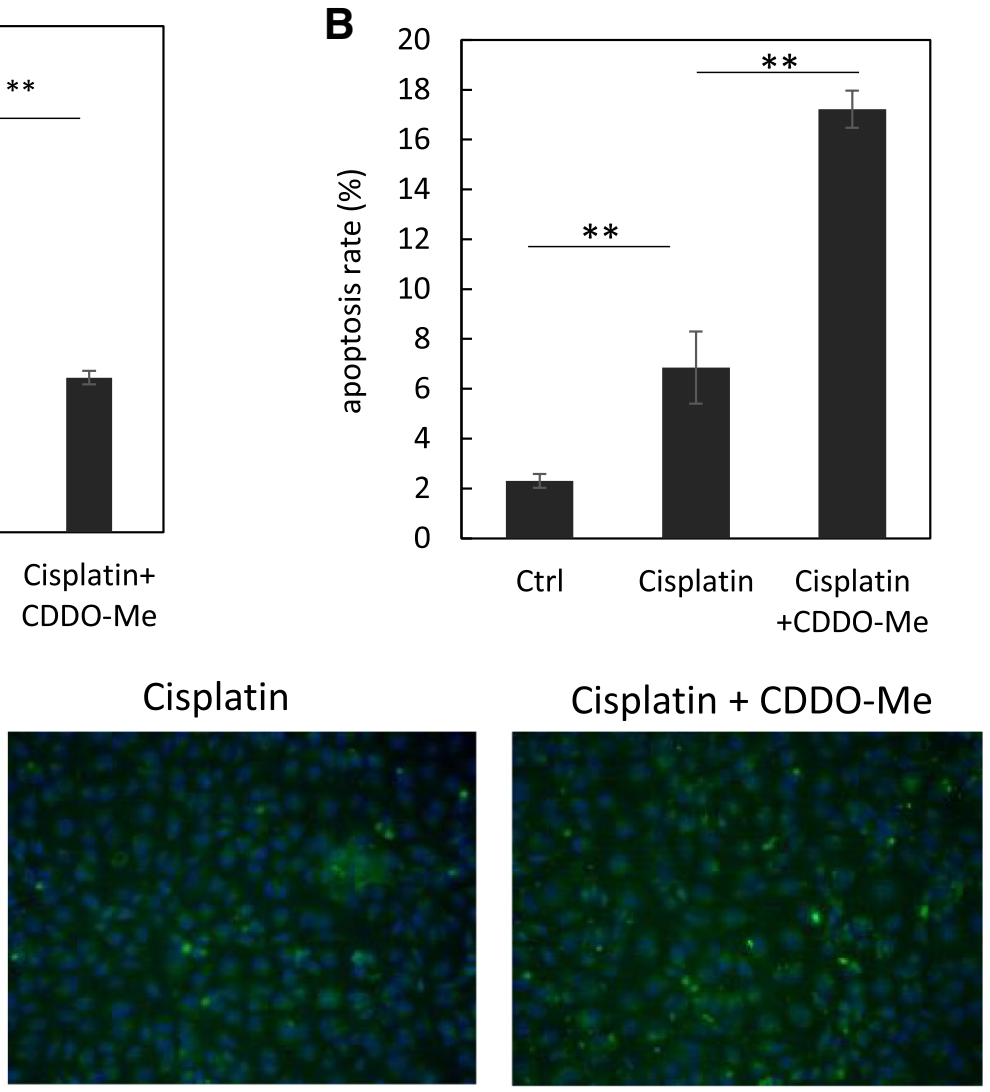

Fig. 6 CDDO-Me treatment decreases the cell number in cisplatinexposed HK-2 cells by inducing apoptosis. Cisplatin $(20 \mu \mathrm{mol} / \mathrm{L})-$ exposed HK-2 cells were cultured in medium with or without $0.2 \mu \mathrm{mol} / \mathrm{L}$ CDDO-Me. Cell numbers were counted at $48 \mathrm{~h}(\mathbf{A}) . n=3$, $* * P<0.01$. Apoptotic cells were detected in cisplatin $(20 \mu \mathrm{mol} / \mathrm{L})-$

of a pool of senescent cells following cisplatin treatment. This was demonstrated by the upregulation of cyclindependent kinase inhibitors, such as $\mathrm{p} 16^{\mathrm{INK} 4 \mathrm{a}}, \mathrm{p} 21^{\text {Waf1/Cip1 }}$, and phosphorylated $\mathrm{Rb}$ in cells exposed to cisplatin for $72 \mathrm{~h}$. An increase in $\mathrm{p} 21^{\mathrm{Waf} 1 / \mathrm{Cip} 1}$ and $\mathrm{p} 16^{\mathrm{INK} 4 \mathrm{a}}$ induces G2/M arrest through the phosphorylation of Rb [40]. Flow cytometric analysis showed an increase in the number of S-phase cells in cisplatin-treated cultures. Thus, cisplatin treatment seemed to be associated with S- or G2/M-phase arrest by regulating $\mathrm{p} 16^{\mathrm{INK} 4 \mathrm{a}}$ and/or $\mathrm{p} 21^{\text {Waf1/Cip1 }}$. Cisplatin stalls cell proliferation by damaging DNA and inhibiting DNA synthesis, which is cytotoxic during the S phase [41]. In fact, $\gamma$-H2AX, a DNA damage marker, was elevated in cisplatintreated cells. Furthermore, cisplatin treatment induced the upregulation and secretion of IL- 6 and IL-8 in the medium. These results indicate that cisplatin-exposed cells undergo premature cellular senescence, consistent with the results from previous studies [30, 31]. exposed cultures after treatment with or without $0.2 \mu \mathrm{mol} / \mathrm{L}$ CDDOMe by TUNEL staining (original magnification $\times 200)(\mathbf{B})$, and the number of apoptotic cells was expressed as the apoptosis rate $(\mathbf{C})$. Data are presented as mean \pm SD from three independent experiments. $* * P<0.01$

This study showed that CDDO-Me treatment decreased senescence markers in PTCs exposed to cisplatin. Upon activation by CDDO-Me, Nrf2 translocates to the nucleus and induces the transcription of antioxidant enzyme genes via the antioxidant response element, ARE [42]. This was demonstrated by the upregulation of the antioxidant enzymes following the CDDO-Me treatment of the cisplatin-treated HK-2 cells. Aleksunes et al. elucidated using in vivo studies that cisplatin accelerates cell proliferation and secretion of IL-1 $\beta$, IL- 6 , and TNF- $\alpha$ in the kidney; importantly, this phenotype was inhibited by CDDO-lm, an analog of CDDO$\mathrm{Me}$, through the increase of Nrf2 signaling [43]. Treatment with the antioxidant $\mathrm{N}$-acetylcysteine ameliorates cellular senescence in PTCs induced by multiple cisplatin treatments [32]. Furthermore, an in vitro study using human PTCs showed that the upregulation of the antioxidant genes by Nrf2 enhanced cell viability [44]. These studies suggest that removing oxidative stress via the Keap1-Nrf2 pathway protects PTCs from cellular senescence. 
A

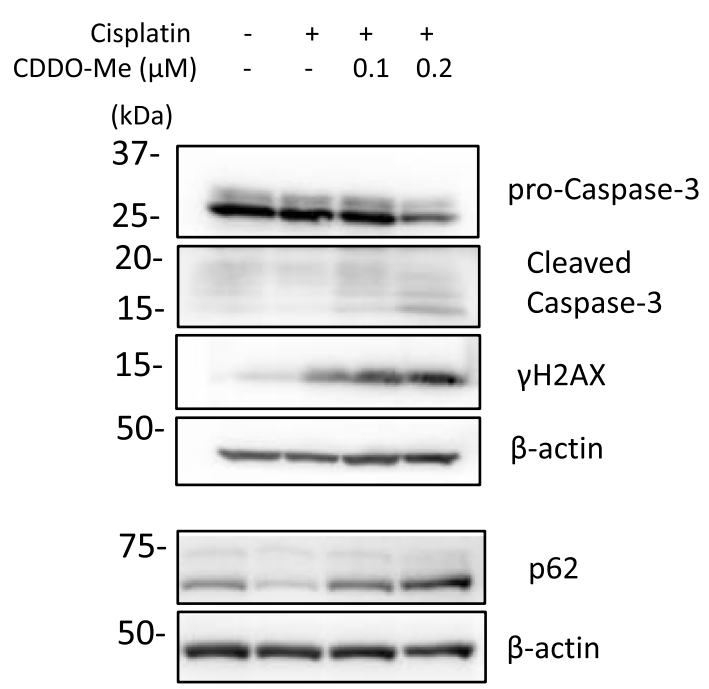

C

$\begin{array}{rllll}\text { Cisplatin } & + & + & + & + \\ \text { CDDO-Me } & - & + & + & + \\ \text { Ac-DEVD-CHO }(\mu \mathrm{M}) & - & - & 5 & 50\end{array}$

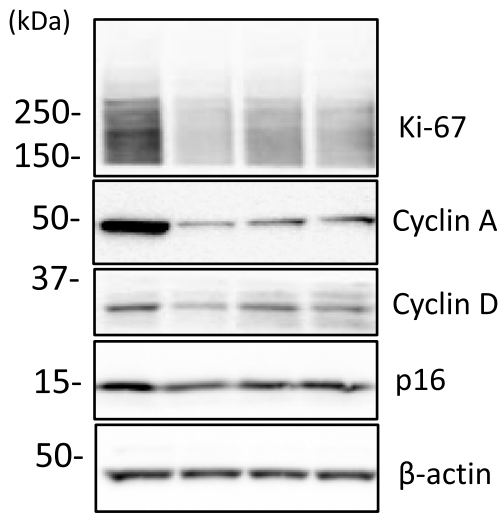

Fig. 7 CDDO-Me induces apoptosis in cisplatin-treated HK-2 cells. HK-2 cells were exposed to $20 \mu \mathrm{mol} / \mathrm{L}$ cisplatin for $6 \mathrm{~h}$, followed by treatment with or without CDDO-Me $(0.1$ or $0.2 \mu \mathrm{mol} / \mathrm{L})$. Apoptotic marker proteins were analyzed by western blotting (A), and protein bands were quantified by densitometry (B). $n=4-6, * P<0.05$, ${ }^{*} P P<0.01$ vs. control (Ctrl), ${ }^{\#} P<0.05$, ${ }^{\# \#} P<0.01$ vs. cisplatin, ${ }^{+} P<0.05,{ }^{++} P<0.01$ vs. cisplatin + CDDO-Me $(0.1 \mu \mathrm{mol} / \mathrm{L})$. Cispl-

Overdosing with CDDO-Me induces apoptosis [28]. Eliminating the senescent cells by activating apoptosis has a protective effect on tissue aging [16-18]. Therefore, we evaluated whether CDDO-Me induced apoptosis and reversed senescence via an apoptotic mechanism. We showed that CDDOM-Me decreased the cell number, which occurs through the apoptotic mechanism. CDDO-Me treatment increased the level of cleaved caspase- 3 and the number of TUNEL-positive cells. Furthermore, CDDO-Me accelerated the phosphorylation of $\mathrm{H} 2 \mathrm{AX}$, which occurs in
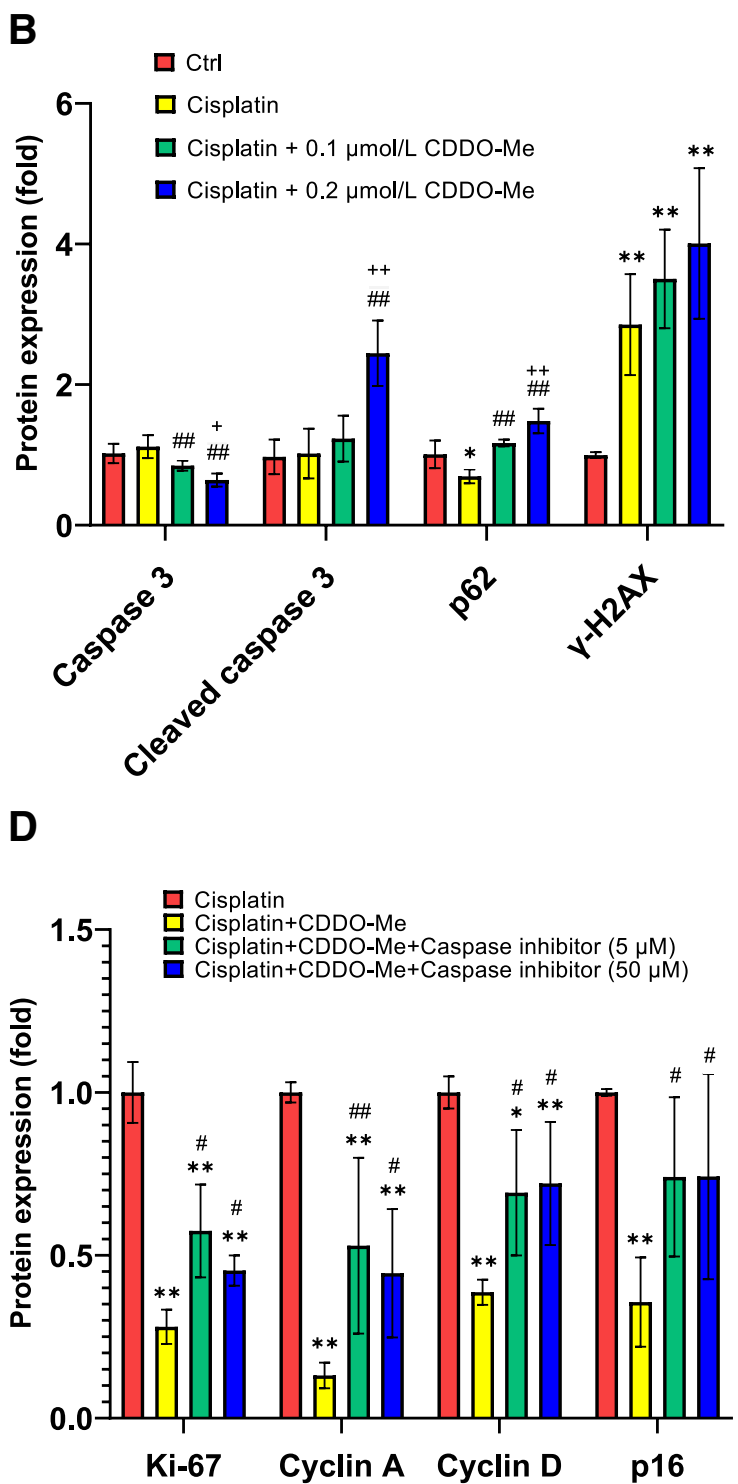

atin-exposed cells were treated with 5 or $50 \mu \mathrm{mol} / \mathrm{L}$ Ac-DEVD-CHO, a caspase inhibitor, for $60 \mathrm{~min}$ prior to adding $0.2 \mu \mathrm{mol} / \mathrm{L}$ CDDO$\mathrm{Me}$ to the medium. Senescence markers were analyzed using western blotting $(\mathbf{C})$ and the expression was quantified using densitometry (D). $\mathrm{n}=4-5,{ }^{*} P<0.05,{ }^{* *} P<0.01$ vs. cisplatin, ${ }^{\#} P<0.05,{ }^{\# \#} P<0.01$ vs. cisplatin + CDDO-Me

response to DNA damage and induces apoptosis by mitochondrial cytochrome $\mathrm{C}$ release [45]. Additionally, CDDOMe increases p62/SQSTM1 expression, which plays a critical role in both autophagy and apoptosis [46, 47]. Inhibition of apoptosis suppressed the reversal effect of CDDO-Me against cisplatin-induced cellular senescence-like alterations. Therefore, CDDO-Me induces apoptosis and suppressed cellular senescence in cisplatin-treated cells. The activation of apoptosis could contribute to the removal of senescent cells and improved kidney functions. 
The use of only one cell line was a limitation of this study. HK-2 cells were used in this study, because senescence could be easily induced by treating the HK-2 cells with D-serine, indoxyl sulfate, and hydrogen peroxide [36-38]. Additionally, HK-2 cells maintain biochemical properties similar to that in the in vivo proximal tubule cells $[48,49]$. Therefore, this model was well-suited for this study. However, HK-2 cells lack expression of organic anion transporter 1,3 , and organic cation transporter 2 , which are important for drug metabolism [50]. Therefore, drug metabolism in HK-2 might not be completely similar to that in the in vivo state. It is unclear whether CDDO-Me removes senescent cells selectively in vivo; therefore, we cannot conclude that activation of apoptosis by CDDO-Me protects against kidney injury in humans. Further in vivo studies are needed to evaluate the protective effect of CDDO-Me against cellular senescence in PTCs.

In conclusion, our results demonstrated a beneficial effect of CDDO-Me on cellular senescence in HK-2 cells. It is hypothesized that this beneficial effect is related to Nrf2 activation. CDDO-Me appears to be a candidate therapeutic for AKI. Our findings also showed that CDDO-Me induced apoptosis in cisplatin-treated HK-2 cells and potentially protects the kidneys from cellular senescence. Future studies are needed to assess the effects of CDDO-Me-induced apoptosis on cellular senescence and kidney function in AKI animal models.

Supplementary Information The online version contains supplementary material available at https://doi.org/10.1007/s11010-021-04295-y.

Author contributions $\mathrm{YK}, \mathrm{MO}, \mathrm{RN}$, and NI provided conception and design of research; YK, AI, FK, and AM performed experiments; YK, AM, and MY analyzed data; YK, FK, MO, TT, TI, MK, and NI interpreted results of experiments; YK, AM, and MY prepared figures; YK drafted manuscript; YK, MO, TT, TI, MK, RN, and NI edited and revised manuscript; YK, AI, FK, MO, AM, MY, TT, TI, MK, RN, and NI approved final version of manuscript.

Funding This work was supported by Kitasato University School of Allied Health Sciences (Grant-in-Aid for Research Project No. 20191053, Nos. 2020-1047, 2021-1022), Kitasato University Research Grant for Young Researchers (2019-19), and JSPS KAKENHI [Grantin-Aid for Scientific Research (C) No. JP19K07944].

Data availability The data used to support the findings of this study are included within the article. All data generated or analyzed during this study are included in this published article and its Supplementary Information.

Code availability Not applicable.

\section{Declarations}

Conflict of interest Not applicable.

Ethical approval Not applicable.
Open Access This article is licensed under a Creative Commons Attribution 4.0 International License, which permits use, sharing, adaptation, distribution and reproduction in any medium or format, as long as you give appropriate credit to the original author(s) and the source, provide a link to the Creative Commons licence, and indicate if changes were made. The images or other third party material in this article are included in the article's Creative Commons licence, unless indicated otherwise in a credit line to the material. If material is not included in the article's Creative Commons licence and your intended use is not permitted by statutory regulation or exceeds the permitted use, you will need to obtain permission directly from the copyright holder. To view a copy of this licence, visit http://creativecommons.org/licenses/by/4.0/.

\section{References}

1. Chawla LS, Eggers PW, Star RA, Kimmel PL (2014) Acute kidney injury and chronic kidney disease as interconnected syndromes. N Engl J Med 371:58-66

2. Coca SG, Singanamala S, Parikh CR (2012) Chronic kidney disease after acute kidney injury: a systematic review and metaanalysis. Kidney Int 81:442-448

3. James MT, Hemmelgarn BR, Wiebe N, Pannu N, Manns BJ, Klarenbach SW et al (2010) Glomerular filtration rate, proteinuria, and the incidence and consequences of acute kidney injury: a cohort study. Lancet 376:2096-2103

4. Takaori K, Nakamura J, Yamamoto S, Nakata H, Sato Y, Takase $M$ et al (2016) Severity and frequency of proximal tubule injury determines renal prognosis. J Am Soc Nephrol 27:2393-2406

5. Westhoff JH, Hilgers KF, Steinbach MP, Hartner A, Klanke B, Amann K et al (2008) Hypertension induces somatic cellular senescence in rats and humans by induction of cell cycle inhibitor p16INK4a. Hypertension 52:123-129

6. Satriano J, Mansoury H, Deng A, Sharma K, Vallon V, Blantz RC et al (2010) Transition of kidney tubule cells to a senescent phenotype in early experimental diabetes. Am J Physiol Cell Physiol 299:C374-C380

7. de Magalhães JP, Passos JF (2018) Stress, cell senescence and organismal ageing. Mech Ageing Dev 170:2-9

8. Childs BG, Durik M, Baker DJ, van Deursen JM (2015) Cellular senescence in aging and age-related disease: from mechanisms to therapy. Nat Med 21:1424-1435

9. Campisi J, d'Adda di Fagagna F (2007) Cellular senescence: when bad things happen to good cells. Nat Rev Mol Cell Biol 8:729-740

10. Soto-Gamez A, Demaria M (2017) Therapeutic interventions for aging: the case of cellular senescence. Drug Discov Today 22:786-795

11. van Deursen JM (2014) The role of senescent cells in ageing. Nature 509:439-446

12. Zhu Y, Tchkonia T, Pirtskhalava T, Gower AC, Ding H, Giorgadze $\mathrm{N}$ et al (2015) The Achilles' heel of senescent cells: from transcriptome to senolytic drugs. Aging Cell 14:644-658

13. Wang E (1995) Senescent human fibroblasts resist programmed cell death, and failure to suppress bcl2 is involved. Cancer Res 55:2284-2292

14. Fuhrmann-Stroissnigg H, Ling YY, Zhao J, McGowan SJ, Zhu Y, Brooks RW et al (2017) Identification of HSP90 inhibitors as a novel class of senolytics. Nat Commun 8:422

15. Kim YM, Seo YH, Park CB, Yoon SH, Yoon G (2010) Roles of GSK3 in metabolic shift toward abnormal anabolism in cell senescence. Ann NY Acad Sci 1201:65-71

16. Baar MP, Brandt RMC, Putavet DA, Klein JDD, Derks KWJ, Bourgeois BRM et al (2017) Targeted apoptosis of senescent cells restores tissue homeostasis in response to chemotoxicity and aging. Cell 169:132-147.e16 
17. Chang J, Yingying W, Shao L, Laberge RM, Demaria M, Campisi J et al (2016) Clearance of senescent cells by ABT263 rejuvenates aged hematopoietic stem cells in mice. Nat Med 22:78-83

18. Yosef R, Pilpel N, Tokarsky-Amiel R, Biran A, Ovadya Y, Cohen $S$ et al (2016) Directed elimination of senescent cells by inhibition of BCL-W and BCL-XL. Nat Commun 7:11190

19. Liby K, Hock T, Yore MM, Suh N, Place AE, Risingsong R et al (2005) The synthetic triterpenoids, CDDO and CDDO-imidazolide, are potent inducers of heme oxygenase- 1 and Nrf2/ARE signaling. Cancer Res 65:4789-4798

20. Dinkova-Kostova AT, Liby KT, Stephenson KK, Holtzclaw WD, Gao X, Suh N et al (2005) Extremely potent triterpenoid inducers of the phase 2 response: correlations of protection against oxidant and inflammatory stress. Proc Natl Acad Sci USA 102:4584-4589

21. Yates MS, Tauchi M, Katsuoka F, Flanders KC, Liby KT, Honda $\mathrm{T}$ et al (2007) Pharmacodynamic characterization of chemopreventive triterpenoids as exceptionally potent inducers of Nrf2regulated genes. Mol Cancer Ther 6:154-162

22. Sporn MB, Liby KT, Yore MM, Fu L, Lopchuk JM, Gribble GW (2011) New synthetic triterpenoids: potent agents for prevention and treatment of tissue injury caused by inflammatory and oxidative stress. J Nat Prod 74:537-545

23. Ruiz S, Pergola PE, Zager RA, Vaziri ND (2013) Targeting the transcription factor Nrf2 to ameliorate oxidative stress and inflammation in chronic kidney disease. Kidney Int 83:1029-1041

24. Pergola PE, Raskin P, Toto RD, Meyer CJ, Huff JW, Grossman EB et al (2011) Bardoxolone methyl and kidney function in CKD with type 2 diabetes. N Engl J Med 365:327-336

25. de Zeeuw D, Akizawa T, Audhya P, Bakris GL, Chin M, Christ-Schmidt $\mathrm{H}$ et al (2013) Bardoxolone methyl in type 2 diabetes and stage 4 chronic kidney disease. N Engl J Med 369:2492-2503

26. Chin M, Lee CY, Chuang JC, Bumeister R, Wigley WC, Sonis ST et al (2013) Bardoxolone methyl analogs RTA 405 and dh404 are well tolerated and exhibit efficacy in rodent models of Type 2 diabetes and obesity. Am J Physiol Ren Physiol 304:F1438-F1446

27. Ding Y, Stidham RD, Bumeister R, Trevino I, Winters A, Sprouse $M$ et al (2013) The synthetic triterpenoid, RTA 405, increases the glomerular filtration rate and reduces angiotensin II-induced contraction of glomerular mesangial cells. Kidney Int 83:845-854

28. Wang YY, Yang YX, Zhao R, Pan ST, Zhe H, He ZX et al (2015) Bardoxolone methyl induces apoptosis and autophagy and inhibits epithelial-to-mesenchymal transition and stemness in esophageal squamous cancer cells. Drug Des Dev Ther 9:993-1026

29. Shord SS, Thompson DM, Krempl GA, Hanigan MH (2006) Effect of concurrent medications on cisplatin-induced nephrotoxicity in patients with head and neck cancer. Anticancer Drugs 17:207-215

30. Yu W, Chen Y, Dubrulle J, Stossi F, Putluri V, Sreekumar A et al (2018) Cisplatin generates oxidative stress which is accompanied by rapid shifts in central carbon metabolism. Sci Rep 8:4306

31. Sun X, Shi B, Zheng H, Min L, Yang J, Li X et al (2018) Senescence-associated secretory factors induced by cisplatin in melanoma cells promote non-senescent melanoma cell growth through activation of the ERK1/2-RSK1 pathway. Cell Death Dis 9:260

32. Li C, Xie N, Li Y, Liu C, Hou FF, Wang J et al (2019) N-acetylcysteine ameliorates cisplatin-induced renal senescence and renal interstitial fibrosis through sirtuin 1 activation and p53 deacetylation. Free Radic Biol Med 130:512-527

33. Li W, Wang W, Li Y, Wang W, Wang T, Li L et al (2014) Proteomics analysis of normal and senescent NG108-15 cells: GRP78 plays a negative role in cisplatin-induced senescence in the NG108-15 cell line. PLoS ONE 9:e90114

34. Kurosaki Y, Imoto A, Kawakami F, Yokoba M, Takenaka T, Ichikawa $\mathrm{T}$ et al (2018) Oxidative stress increases megalin expression in the renal proximal tubules during the normoalbuminuric stage of diabetes mellitus. Am J Physiol Ren Physiol 314:F462-F470
35. de Zeeuw D, Akizawa T, Agarwal R, Audhya P, Bakris GL, Chin $M$ et al (2013) Rationale and trial design of Bardoxolone Methyl Evaluation in Patients with Chronic Kidney Disease and Type 2 Diabetes: the Occurrence of Renal Events (BEACON). Am J Nephrol 37:212-222

36. Okada A, Nangaku M, Jao TM, Maekawa H, Ishimono Y, Kawakami $\mathrm{T}$ et al (2017) D-serine, a novel uremic toxin, induces senescence in human renal tubular cells via GCN2 activation. Sci Rep 7:11168

37. Shimizu H, Bolati D, Adijang A, Muteliefu G, Enomoto A, Nishijima $F$ et al (2011) NF- $\kappa B$ plays an important role in indoxyl sulfate-induced cellular senescence, fibrotic gene expression, and inhibition of proliferation in proximal tubular cells. Am J Physiol Cell Physiol 301:C1201-C1212

38. Jia Y, Kang X, Tan L, Ren Y, Qu L, Tang J et al (2021) Nicotinamide mononucleotide attenuates renal interstitial fibrosis after AKI by suppressing tubular DNA damage and senescence. Front Physiol 12:649547

39. Samikkannu T, Thomas JJ, Bhat GJ, Wittman V, Thekkumkara TJ (2006) Acute effect of high glucose on long-term cell growth: a role for transient glucose increase in proximal tubule cell injury. Am J Physiol Ren Physiol 291:F162-F175

40. Gire V, Dulic V (2015) Senescence from G2 arrest, revisited. Cell Cycle 14:297-304

41. Donaldson KL, Goolsby GL, Wahl AF (1994) Cytotoxicity of the anticancer agents cisplatin and taxol during cell proliferation and the cell cycle. Int J Cancer 57:847-855

42. Itoh K, Chiba T, Takahashi S, Ishii T, Igarashi K, Oyake T et al (1997) An Nrf2/small Maf heterodimer mediates the induction of phase II detoxifying enzyme genes through antioxidant response elements. Biochem Biophys Res Commun 236:313-322

43. Aleksunes LM, Goedken MJ, Rockwell CE, Thomale J, Manautou JE, Klaassen CD (2010) Transcriptional regulation of renal cytoprotective genes by Nrf2 and its potential use as a therapeutic target to mitigate cisplatin-induced nephrotoxicity. J Pharmacol Exp Ther 335:2-12

44. Atilano-Roque A, Wen X, Aleksunes LM, Joy MS (2016) Nrf2 activators as potential modulators of injury in human kidney cells. Toxicol Rep 12(3):153-159

45. Plesca D, Mazumder S, Almasan A (2008) DNA damage response and apoptosis. Methods Enzymol 446:107-122

46. Islam MA, Sooro MA, Zhang P (2018) Autophagic regulation of p62 is critical for cancer therapy. Int J Mol Sci 19:1405

47. Jung KT, Oh SH (2019) Polyubiquitination of p62/SQSTM1 is a prerequisite for Fas/CD95 aggregation to promote caspasedependent apoptosis in cadmium-exposed mouse monocyte RAW264.7 cells. Sci Rep 9:12240

48. Gunness P, Aleksa K, Kosuge K, Ito S, Koren G (2010) Comparison of the novel HK-2 human renal proximal tubular cell line with the standard LLC-PK1 cell line in studying drug-induced nephrotoxicity. Can J Physiol Pharmacol 88:448-455

49. Paolicchi A, Sotiropuolou M, Perego P, Daubeuf S, Visvikis A, Lorenzini E et al (2003) Gamma-glutamyl transpeptidase catalyses the extracellular detoxification of cisplatin in a human cell line derived from the proximal convoluted tubule of the kidney. Eur J Cancer 39:996-1003

50. Jankinson SE, Chung GW, Loon EV, Bakar NS, Daizell AM, Brown CDA (2012) The limitations of renal epithelial cell line HK-2 as a model of drug transporter expression and function in the proximal tubule. Pflugers Arch 464:601-611

Publisher's Note Springer Nature remains neutral with regard to jurisdictional claims in published maps and institutional affiliations. 